\title{
Recent trends in postoperative mortality after liver resection- A systemic review and metanalysis of studies published in last 5 years and metaregression of various factors affecting 90 days mortality.
}

Dr. Bhavin Vasavada,

Consultant hepatobiliary and liver transplant surgeon,

Department of hepatobiliary and liver transplant surgery,

Shalby Hospitals,

Ahmedabad.

Email: drbhavin.liversurgeon@gmail.com.

\section{Dr.Hardik Patel}

Consultant hepatobiliary and liver transplant surgeon,

Department of hepatobiliary and liver transplant surgery,

Shalby Hospitals,

Ahmedabad.

Key words: Liver resection; 90-day mortality; hepatectomy, perioperative outcomes, hepatocellular carcinoma.

Conflict of Interests: None

Funding disclosure: nothing to disclose. 


\begin{abstract}
:
Aim: The aim of this systemic review and meta-analysis was to analyse 90 days mortality after liver resection, and also study various factors associated with mortality via univariate and multivariate metaregression.
\end{abstract}

\title{
Methods:
}

PubMed, Cochrane library, Embase, google scholar, web of science with keywords like 'liver resection"; "mortality"," hepatectomy". Weighted percentage 90 days mortalities were analysed. univariate metaregression was done by DerSimonian-Liard methods. Major hepatectomy, open surgery, cirrhotic livers, blood loss, hepatectomy for hepatocellular carcinoma, hepatectomy for colorectal liver metastasis were taken as moderators in metaregression analysis. We decided to enter all co-variants in multivariate model to look for mixed effects. Heterogeneity was assessed using the Higgins $\mathrm{I}^{2}$ test, with values of $25 \%, 50 \%$ and $75 \%$ indicating low, moderate and high degrees of heterogeneity. Cohort studies were assessed for bias using the Newcastle-Ottawa Scale to assess for the risk of bias. Publication bias was assessed using funnel plot. Funnel plot asymmetry was evaluated by Egger's test.

\section{Results:}

Total 29931 patients' data who underwent liver resections for various etiologies were pooled from 41 studied included 1257 patients died within 90 days post operatively. Weighted 90 days mortality was $3.6 \%$ (95\% C.I $2.8 \%-4.4 \%$ ). However, heterogeneity of the analysis was high with $\mathrm{I}^{2} 94.625 \%$. $(\mathrm{p}<0.001)$. We analysed various covariates like major hepatectomy, Age of the patient, blood loss, open surgery, liver resections done for hepatocellular carcinoma or colorectal liver metastasis and cirrhotic liver to check for their association with heterogeneity in the analysis and hence 90 days mortality. On 
univariate metaregression analysis major hepatectomy $(\mathrm{p}<0.001)$, Open hepatectomy $(\mathrm{p}<0.001)$, blood loss $(\mathrm{p}=0.002)$ was associated with heterogeneity in the analysis and 90 days mortality. On multivariate metaregression Major hepatectomy(p=0.003) and Open surgery $(\mathrm{p}=0.012)$ was independently associated with higher 90 days mortality, and liver resection for colorectal liver metastasis was independently associated with lesser 90 days mortality $\quad(\mathrm{z}=\quad-4.11, \mathrm{p}<0.01)$ Residual heterogeneity after all factor multivariate metaregression model $\quad$ was $\quad$ none $\quad\left(\mathrm{I}^{2}=0, \operatorname{Tau}^{2}=0, \quad \mathrm{H}^{2}=1\right)$ and nonsignificant $(\mathrm{p}=0.49)$.

\section{Conclusion:}

Major hepatectomy, open hepatectomy, and cirrhotic background is associated with higher mortality rates and colorectal liver metastasis is associated with lower peri operative mortality rates. 
medRxiv preprint doi: https://doi.org/10.1101/2021.03.26.21254407; this version posted March 29, 2021. The copyright holder for this preprint (which was not certified by peer review) is the author/funder, who has granted medRxiv a license to display the preprint in perpetuity.

It is made available under a CC-BY-ND 4.0 International license .

\section{Introduction:}

Liver resection is now established curative treatment for various malignant and benign liver pathology. Currently Hepatocellular carcinoma and colorectal liver metastasis is the most common indications for liver surgery as well as primary and secondary liver malignancies. $[1,2]$.

Perioperative care and surgical techniques for liver resections have improved significantly in past few years, resulting in improved perioperative outcomes. However, despite improvements liver resections are associated with variable outcomes according to centres, countries and surgeons and mortality and morbidity rates after this demanding surgery are still high and variable. [3,4,5]. There is also lack of uniformity in the literature regarding description of post-operative mortality with some mention in hospital mortality, some 30 days mortality and some 90 days mortality.

Recently published study by Filmann et al.[6] suggested higher In hospital mortality rate across the Germany. However due to lack of data they also could not report actual 90 days mortality data and mentioned in hospital mortality rates. However, their findings raised concerns about under reporting of mortality data in scientific community.

Aim of this systemic review and meta-analysis was to analyse 90 days mortality after liver resection, and study various factors associated with mortality via univariate and multivariate metaregression.

\section{Material and Methods:}

The study was conducted according to the Preferred Reporting Items for Systematic Reviews and Meta-Analyses (PRISMA) statement and MOOSE guidelines. [7,8]. We conducted literature search as described by Gossen et al. [9]. PubMed, Cochrane library, Embase, google scholar, web of science with keywords like "liver resection"; "mortality";" hepatectomy". Two independent authors extracted the data (B.V and H.P). We evaluated last 
medRxiv preprint doi: https://doi.org/10.1101/2021.03.26.21254407; this version posted March 29, 2021. The copyright holder for this preprint (which was not certified by peer review) is the author/funder, who has granted medRxiv a license to display the preprint in perpetuity.

It is made available under a CC-BY-ND 4.0 International license .

studies published in last 5 years to see recent trends in 90 days mortality. In case of disagreements decision reached on basis of discussions.

\section{Definitions:}

Major hepatectomy was defined as resection of more than or equal to 3 segments. Postoperative mortality was defined as any mortality within 90 days post-operative period.

\section{Statistical Analysis:}

The meta-analysis was done using Review Manager 5.4 and JASP Team (2020). JASP (Version 0.14.1)(University of Amsterdam). Weighted percentage 90 days mortalities with $95 \%$ confidence intervals were used. Univariate metaregression was done by DerSimonian-Liard methods. Major hepatectomy, open surgery, cirrhotic livers, blood loss, hepatectomy for hepatocellular carcinoma, hepatectomy for colorectal liver metastasis were taken as co-variates in metaregression analysis to study their association heterogeneity of the meta-analysis and 90 days mortality. Factors with $\mathrm{p}$ value less than 0.05 were entered in multivariate metaregression model and then we decided to check for residual heterogeneity, if residual heterogeneity is still significant, we decided to enter all co-variants in multivariate model to look for mixed effects. Heterogeneity was assessed using the Higgins $\mathrm{I}^{2}$ test, with values of $25 \%, 50 \%$ and $75 \%$ indicating low, moderate and high degrees of heterogeneity, respectively and assessed $\mathrm{p}$ value for significance of heterogeneity and $\operatorname{tau}^{2}$ and $\mathrm{H}^{2}$ value [10]. The random effects model was used in meta-analysis.

\section{Assessment of Bias:}

Cohort studies were assessed for bias using the Newcastle-Ottawa Scale to assess for the risk of bias [11,12] Publication bias was assessed using funnel plot. Funnel plot asymmetry was evaluated by Egger's test.

\section{Inclusion and Exclusion criteria for studies:}




\section{Inclusion criteria:}

- Studies with full texts

- Studies published in last 5 years.

- Studies mentioning 90 days mortality rates.

- Studies which evaluated liver resections for different etiologies.

- Studies published in last 5 years.

- English language studies.

\section{Exclusion criteria:}

- Studies which were not fulfilling above criteria.

Duplicate studies.

Studies which included analysis of liver resection for single etiology.

\section{Results:}

\section{Data extraction, study characteristics and quality assessment:}

'PUBMED', 'SCOPUS', and 'EMBASE' databases were searched using keywords and the search strategy described above. Initially 4246 studies published in last 5 years were screened from above search strategy and 23 additional records were screened from references of above studies. After removing duplicates 3343 studies screened again. 3265 studies 
excluded meeting the exclusion criteria. 78 full text articles were evaluated. 36 full texts article removed as they did not mention 90 days mortality and instead mentioned in hospital, perioperative or 30 days post-operative mortality.41 studies included in final qualitative and quantitative analysis. [Figure 1 Prisma flow chart]. Risk of bias summary is mentioned in Figure 2. Study characteristics are mentioned in table 1. All the studies included are either retrospective studies or propensity score matched analysis from retrospective data. In propensity score matched analysis unmatched total data were analysed for 90 days mortality, so effectively all the data were retrospective.

\section{Weighted 90 days mortality:}

Total 29931 patients' data who underwent liver resections for various etiologies were pooled from 41 studied included.[13-52].1257 patients died within 90 days post operatively. Weighted 90 days mortality was $3.6 \%$ with $95 \%$ confidence interval between $2.8 \%$ to $4.4 \%$.

[Figure 3 Forest plot]. However, heterogeneity of the analysis was high with $\mathrm{I}^{2} 94.625 \%$, $\operatorname{tau}^{2} 0.001$, and $\mathrm{Q}$ value of 744.188. $\mathrm{P}$ value of heterogeneity was highly significant $(\mathrm{p}<0.001)$.

\section{Publication Bias:}

Figure 4 mentioned significant publication bias. Egger's test showed significant publication bias with $\mathrm{p}$ value of $<0.001$.

\section{Metaregression analysis:}

We analysed various covariates like major hepatectomy, Age of the patient, blood loss, open surgery, liver resections done for hepatocellular carcinoma or colorectal liver metastasis and cirrhotic liver to check for their association with heterogeneity in the analysis and hence 90 days mortality.

On univariate metaregression analysis major hepatectomy $(\mathrm{p}<0.001)$, Open hepatectomy $(\mathrm{p}<0.001)$, blood loss $(\mathrm{p}=0.002)$ were associated with heterogeneity in the 
analysis and 90 days mortality. On multivariate metaregression model after entering above 3 factors which were significant in univariate model, blood loss was significantly associated with heterogeneity and 90 days mortality. ( $\mathrm{p}$ value= 0.03 ). However, residual heterogeneity was still highly significant with $\mathrm{I}^{2} 75.74 \%$ and $\mathrm{p}<0.001$. So, we entered all the factors in multivariate model. On all covariates multivariate model, Major hepatectomy $(\mathrm{p}=0.003)$ and Open surgery $(\mathrm{p}=0.012)$ was independently associated with higher 90 days mortality, and liver resection for colorectal liver metastasis was independently associated with lesser 90 days mortality $\quad(\mathrm{z}=\quad-4.11, \mathrm{p}<0.01) . \quad$ Residual heterogeneity after all factor multivariate metaregression model $\quad$ was $\quad$ none $\quad\left(\mathrm{I}^{2}=0, \mathrm{Tau}^{2}=0, \quad \mathrm{H}^{2}=1\right)$ and nonsignificant $(\mathrm{p}=0.49)$ suggesting homogeneity of the findings. However only 10 studies mentioned all the factors. Metaregression forest plots for each parameters) is mentioned in supplement Figure 1 and multivariate forest plot (All Factors) mentioned in Figure 5. Funnel plot of studies mentioned all the factors and entered in multivariate model showed no publication bias. ( $\mathrm{p}=0.285$ by eggers' test). [Figure 6]. Normal Q-Q plot after meta-regression analysis is shown in Figure 7.

\section{Discussion:}

Liver resection is a curative surgery for many benign and malignant disorders, with most common indications are hepatocellular carcinoma and colorectal liver metastasis. Liver resection was historically associated with very high morbidity and mortality, which has now decreased significantly due to improved surgical and anaesthetic technique and improved perioperative and critical care. However, it is still considered to be associated with high mortality. Particularly recent study by Filmann et al [6], showed very high 30 days mortality after liver resection in Germany, they also raised concerns about possible selection and reporting bias in mortality studies. 
There is also wide variation in defining peri/post-operative mortality in liver surgeries with some centres reporting in hospital mortality, some centres reporting 30 days and some centres reports 90 days mortality. Mayo et al [53] described that 90 days after surgery should be the standard criteria for defining peri/post-operative mortality. There is also wide regional variations in indications of liver resections. In Asian countries most common indication is hepatocellular carcinoma [54] while in European countries most common indications is colorectal metastasis, which can also be reason of variable mortality following liver resection. Our Aim in conducting this systemic review and prevalence meta-analysis to study weighted post-operative mortality rates after liver resections. We also aimed to look at the heterogeneity of the analysis and publication bias. We also did metaregression analysis for various factor affecting mortality like Major or minor hepatectomy, blood loss, age of the patient, open vs laparoscopic liver resections, cirrhotic background of the liver and etiologies for resections like hepatocellular carcinoma and colorectal metastasis in study published in last 5 year to look for recent trends. As we wanted to analyse 90 days mortality as standard definitions we excluded all the studies which did not mention 90 days mortality and excluded studies which studied only hepatocellular carcinoma or colorectal liver metastasis and included studies which analysed mortality rates in liver resections performed for various etiologies.

As shown in Figure 3 weighted 90 days mortality after liver resection was $3.6 \%$ with $95 \%$ confidence interval between $2.8 \%-4.4 \%$. However, heterogeneity was significantly high with $\mathrm{I}^{2}=94.63 \%$ and $\mathrm{p}$ value $<0.001$. Suggesting various Moderators was responsible for this variable effect sizes in different studies. There was also significant publication bias as shown in funnel plot [Figure 4], and egger's test was also significantly positive for publication bias. 
Therefor we evaluated various factors affecting mortality like age, major hepatectomy, open surgery, blood loss, cirrhotic background, liver resection for hepatocellular carcinomas and colorectal liver metaanalysis.

In univariate metaregression analysis major hepatectomy, open surgery and blood loss was significantly associated with heterogeneity of analysis. When we initially performed metaregression analysis including factors those were significant in univariate analysis, residual heterogeneity of the analysis was still highly significant suggesting various other factors or mixed effect of various factors on mortality was responsible for heterogeneity. So to evaluate that we entered all the factors available in the metaregression model. That showed no residual heterogeneity with $\mathrm{I}^{2}=0, \mathrm{Tau}^{2}=0$ and $\mathrm{H}^{2}=1$ with nonsignificant $\mathrm{p}$ value of the heterogeneity $(\mathrm{p}=0.49)$ suggesting mixed effect of all the factors was responsible for variable effect size and mortality in studies. In multivariate metaregression with all the moderators open hepatectomy $(\mathrm{p}=0.012)$, Major hepatectomy ( $\mathrm{p}=0.003)$, and cirrhotic liver $(\mathrm{p}=0.003)$ was independently associated with higher mortality and colorectal metastasis was independently associated with lower 90 days mortality. $(\mathrm{p}<0.0001, \mathrm{z}=-4.116)$. Elimination of residual heterogeneity after metaregression suggested that above factors was mainly responsible for variable outcomes across the centres. Q-Q plot also suggested lack of heterogeneity after metaregression. [Figure 7].

Limitations of the meta-analysis were some large number studies had to be excluded due to lack of 90 days mortality data for example filmann et al [6] study which evaluated 30 days mortality rate in Germany. Also, we could not take in account centre volume and surgeon's experience. Another limitations was only 10 studies mentioned all the moderators however, number of study was adequate to conduct metaregression analysis. 
However, to our knowledge this is the first meta-analysis evaluated weighted 90 days mortality rates and evaluated various factors responsible for heterogeneity and lack of residual heterogeneity after metaregression proved their effects on variable mortality rates across the centres.

In conclusion reporting of perioperative mortality rates should be standardised as 90 days mortality rates and, they should be evaluated in context of various moderators described above. Major hepatectomy, open hepatectomy, and cirrhotic background is associated with higher mortality rates and colorectal liver metastasis is associated with lower peri operative mortality rates compared to other etiologies like hepatocellular carcinoma.

References:

1. Wallace MC, Preen D, Jeffrey GP et al (2015) The evolving epidemiology of hepatocellular carcinoma: a global perspective. Expert Rev Gastroenterol Hepatol 9(6):765-779.

2. Menfredi S, Lepage C, Hatem C et al (2006) Epidemiology and management of liver metastases from colorectal cancer. Ann Surg. 244(2):254.

3. Gilg S, Sandstro“m P, Rizell M et al (2018) The impact of post hepatectomy liver failure on mortality: a population-based study. Scand J Gastroenterol 25:1-5 
medRxiv preprint doi: https://doi.org/10.1101/2021.03.26.21254407; this version posted March 29, 2021. The copyright holder for this preprint (which was not certified by peer review) is the author/funder, who has granted medRxiv a license to display the preprint in perpetuity.

It is made available under a CC-BY-ND 4.0 International license .

4. Ray S, Mehta NN, Golhar A et al (2018) Post hepatectomy liver failure-A comprehensive review of current concepts and controversies.Ann Med Surg 34:4-10.

5. Kauffmann R, Fong Y (2014) Post-hepatectomy liver failure. Hepatobiliary Surg Nutr 3(5):238.

6. Filmann N, Walter D, Schadde E, et al. Mortality after liver surgery in Germany. $B r J$ Surg. 2019;106(11):1523-1529.

7. Liberati A, Altman DG, Tetzlaff J, et al. (2009) The PRISMA statement for reporting systematic reviews and meta-analyses of studies that evaluate healthcare interventions: explanation and elaboration. BMJ 339:b2700.

8. Stroup DF, Berlin JA, Morton SC, et al. Meta-analysis of observational studies in epidemiology: a proposal for reporting. Meta-analysis Of Observational Studies in Epidemiology (MOOSE) group. JAMA. 2000;283(15):2008-2012.

9. Goossen K, Tenckhoff S, Probst P, et al. Optimal literature search for systematic reviews in surgery. Langenbecks Arch Surg. 2018;403(1):119-129.

10. Higgins JP, Thompson SG, Deeks JJ, Altman DG. Measuring inconsistency in metaanalyses. BMJ 2003; 327: 557-60.

11. Cochrane handbook for systematic reviews of interventions version 5.1.0 [updated March 2011]. Edited by Higgins JPT, Green S. [http://www. cochrane-handbook.org]

12. Wells G, Shea B, O'Connell D, Peterson J, Welch V, Losos M, Tugwell P: The Newcastle-Ottawa Scale (NOS) for assessing the quality of nonrandomised studies in meta-analyses.

In 2013.http://www.ohri.ca/programs/clinical_epidemiology/oxford.asp.

13. Al-Saeedi M, Ghamarnejad O, Khajeh E, et al. Pringle Maneuver in Extended Liver Resection: A propensity score analysis. Sci Rep. 2020;10(1):8847. 
medRxiv preprint doi: https://doi.org/10.1101/2021.03.26.21254407; this version posted March 29, 2021. The copyright holder for this preprint (which was not certified by peer review) is the author/funder, who has granted medRxiv a license to display the preprint in perpetuity.

It is made available under a CC-BY-ND 4.0 International license .

14. Al-Saif FA, Aldekhayel MK, Al-Alem F, Hassanain MM, Mattar RE, Alsharabi A. Comparison study between open and laparoscopic liver resection in a Saudi tertiary center. Saudi Med J. 2019;40(5):452-457.

15. Al-Alem F, Mattar RE, Fadl OA, Alsharabi A, Al-Saif F, Hassanain M. Morbidity and mortality and predictors of outcome following hepatectomy at a Saudi tertiary care center. Ann Saudi Med. 2016;36(6):414-421.

16. Amico EC, Alves JR, João SA, Guimarães PL, Medeiros JA, Barreto ÉJ. IMMEDIATE COMPLICATIONS AFTER 88 HEPATECTOMIES - BRAZILIAN CONSECUTIVE SERIES. Arq Bras Cir Dig. 2016 Jul-Sep;29(3):180-184.

17. Attili A, Sucandy I, Spence J, Bourdeau T, Ross S, Rosemurgy A. Outcomes of extended hepatectomy for hepatobiliary tumors. Initial experience from a nonuniversity hepatobiliary center. Am J Surg. 2020;219(1):106-109.

18. Braunwarth E, Primavesi F, Göbel G, et al. Is bile leakage after hepatic resection associated with impaired long-term survival?. Eur J Surg Oncol. 2019;45(6):10771083.

19. Chin KM, Koh YX, Syn N, et al. Early Prediction of Post-hepatectomy Liver Failure in Patients Undergoing Major Hepatectomy Using a PHLF Prognostic Nomogram. World J Surg. 2020;44(12):4197-4206.

20. Chopinet S, Grégoire E, Bollon E, et al. Short-term outcomes after major hepatic resection in patients with cirrhosis: a 75-case unicentric western experience. $H P B$ (Oxford). 2019;21(3):352-360.

21. Cieslak KP, Bennink RJ, de Graaf W, et al. Measurement of liver function using hepatobiliary scintigraphy improves risk assessment in patients undergoing major liver resection. $H P B$ (Oxford). 2016;18(9):773-780. 
medRxiv preprint doi: https://doi.org/10.1101/2021.03.26.21254407; this version posted March 29, 2021. The copyright holder for this preprint (which was not certified by peer review) is the author/funder, who has granted medRxiv a license to display the preprint in perpetuity.

It is made available under a CC-BY-ND 4.0 International license .

22. Dasari BVM, Hodson J, Sutcliffe RP, et al. Developing and validating a preoperative risk score to predict 90-day mortality after liver resection. J Surg Oncol. 2019;119(4):472-478.

23. Diggs LP, Aversa JG, Wiemken TL, et al. Patient Comorbidities Drive High Mortality Rates Associated with Major Liver Resections Irrespective of Hospital Volume [published online ahead of print, 2020 Dec 19]. Am Surg. 2020;3134820973368.

24. Duarte VC, Coelho FF, Valverde A, et al. Minimally invasive versus open right hepatectomy: comparative study with propensity score matching analysis. BMC Surg. 2020;20(1):260.

25. Fujii Y, Nanashima A, Hiyoshi M, Imamura N, Yano K, Hamada T. Risk factors for hepatic insufficiency after major hepatectomy in non-cirrhotic patients. Asian J Surg. 2019;42(1):251-255.

26. Garnier J, Faucher M, Marchese U, et al. Severe acute kidney injury following major liver resection without portal clamping: incidence, risk factors, and impact on shortterm outcomes. HPB (Oxford). 2018;20(9):865-871.

27. Gelli M, Allard MA, Farges O, et al. Use of aspirin and bleeding-related complications after hepatic resection. Br J Surg. 2018;105(4):429-438.

28. Gilg S, Sparrelid E, Isaksson B, Lundell L, Nowak G, Strömberg C. Mortality-related risk factors and long-term survival after 4460 liver resections in Sweden-a populationbased study. Langenbecks Arch Surg. 2017;402(1):105-113.

29. Goh BK, Teo JY, Chan CY, et al. Evolution of laparoscopic liver resection at Singapore General Hospital: a nine-year experience of 195 consecutive resections. Singapore Med J. 2017;58(12):708-713.

30. Gray AD, Petrou G, Rastogi P, Begbie S. Elective hepatic resection is feasible and safe in a regional centre. ANZ J Surg. 2018 Mar;88(3):E147-E151. 
medRxiv preprint doi: https://doi.org/10.1101/2021.03.26.21254407; this version posted March 29, 2021. The copyright holder for this preprint (which was not certified by peer review) is the author/funder, who has granted medRxiv a license to display the preprint in perpetuity.

It is made available under a CC-BY-ND 4.0 International license .

31. Gupta AK, Kanhere HA, Maddern GJ, Trochsler MI. Liver resection in octogenarians: are the outcomes worth the risk? ANZ J Surg. 2018 Nov;88(11):E756E760.

32. Gyoeri GP, Pereyra D, Braunwarth E, et al. The 3-60 criteria challenge established predictors of postoperative mortality and enable timely therapeutic intervention after liver resection. Hepatobiliary Surg Nutr. 2019;8(2):111-124.

33. Halls MC, Cipriani F, Berardi G, et al. Conversion for Unfavorable Intraoperative Events Results in Significantly Worse Outcomes During Laparoscopic Liver Resection: Lessons Learned From a Multicenter Review of 2861 Cases. Ann Surg. 2018;268(6):1051-1057.

34. Higashi T, Hayashi H, Taki K, et al. Sarcopenia, but not visceral fat amount, is a risk factor of postoperative complications after major hepatectomy [published correction appears in Int J Clin Oncol. 2017 Oct;22(5):986-990]. Int J Clin Oncol. 2016;21(2):310-319.

35. Hobeika C, Fuks D, Cauchy F, et al. Impact of cirrhosis in patients undergoing laparoscopic liver resection in a nationwide multicentre survey. Br J Surg. 2020;107(3):268-277.

36. Khaoudy I, Farges O, Boleslawski E, et al. Half of Postoperative Deaths After Hepatectomy may be Preventable: A Root-cause Analysis of a Prospective Multicenter Cohort Study. Ann Surg. 2018;268(5):792-798.

37. Lee KF, Chong C, Cheung S, et al. Robotic versus open hemihepatectomy: a propensity score-matched study [published online ahead of print, 2020 Nov 13]. Surg Endosc. 2020;10.1007/s00464-020-07645-x. 
38. Lemke M, Karanicolas PJ, Habashi R, et al. Elevated Lactate is Independently Associated with Adverse Outcomes Following Hepatectomy. World J Surg. 2017;41(12):3180-3188.

39. Levi Sandri GB, Colasanti M, Vennarecci G, et al. A 15-year experience of two hundred and twenty five consecutive right hepatectomies. Dig Liver Dis. 2017;49(1):50-56.

40. Lin S, Wu F, Wang L, et al. Surgical outcomes of hand-assisted laparoscopic liver resection $v s$. open liver resection: A retrospective propensity score-matched cohort study. Chin J Cancer Res. 2019;31(5):818-824.

41. Longbotham D, Young A, Nana G, et al. The impact of age on post-operative liver function following right hepatectomy: a retrospective, single centre experience. $H P B$ (Oxford). 2020;22(1):151-160.

42. Donadon M, Fontana A, Palmisano A, et al. Individualized risk estimation for postoperative morbidity after hepatectomy: the Humanitas score. HPB (Oxford). 2017;19(10):910-918.

43. Ome Y, Hashida K, Yokota M, Nagahisa Y, Okabe M, Kawamoto K. The safety and efficacy of laparoscopic hepatectomy in obese patients. Asian J Surg. 2019;42(1):180188.

44. Pietrasz D, Fuks D, Subar D, et al. Laparoscopic extended liver resection: are postoperative outcomes different?. Surg Endosc. 2018;32(12):4833-4840.

45. Ratti F, Cipriani F, Reineke R, et al. The clinical and biological impacts of the implementation of fast-track perioperative programs in complex liver resections: A propensity score-based analysis between the open and laparoscopic approaches. Surgery. 2018;164(3):395-403. 
46. Ruzzenente A, Conci S, Ciangherotti A, et al. Impact of age on short-term outcomes of liver surgery: Lessons learned in 10-years' experience in a tertiary referral hepatopancreato-biliary center. Medicine (Baltimore). 2017;96(20):e6955.

47. Begum S, Khan MR. Short-term outcomes after hepatic resection : perspective from a developing country. J Pak Med Assoc. 2017;67(8):1242-1247.

48. Urbani L, Colombatto P, Balestri R, et al. Techniques of parenchyma-sparing hepatectomy for the treatment of tumors involving the hepatocaval confluence: A reliable way to assure an adequate future liver remnant volume. Surgery. 2017;162(3):483-499.

49. van Mierlo KMC, Lodewick TM, Dhar DK, et al. Validation of the peak bilirubin criterion for outcome after partial hepatectomy. HPB (Oxford). 2016;18(10):806-812.

50. Viganò L, Torzilli G, Aldrighetti L, et al. Stratification of Major Hepatectomies According to Their Outcome: Analysis of 2212 Consecutive Open Resections in Patients Without Cirrhosis. Ann Surg. 2020;272(5):827-833.

51. Worhunsky DJ, Dua MM, Tran TB, et al. Laparoscopic hepatectomy in cirrhotics: safe if you adjust technique. Surg Endosc. 2016;30(10):4307-4314.

52. Yip VS, Dunne DF, Samuels S, et al. Adherence to early mobilisation: Key for successful enhanced recovery after liver resection. Eur $J$ Surg Oncol. 2016;42(10):1561-1567.

53. Mayo SC, Shore AD, Nathan H, et al. Refining the definition of perioperative mortality following hepatectomy using death within 90 days as the standard criterion. HPB (Oxford). 2011;13(7):473-482.

54. Chang CM, Yin WY, Su YC, et al. Preoperative risk score predicting 90-day mortality after liver resection in a population-based study. Medicine (Baltimore). 2014;93(12):e59. 
medRxiv preprint doi: https://doi.org/10.1101/2021.03.26.21254407; this version posted March 29, 2021. The copyright holder for this preprint (which was not certified by peer review) is the author/funder, who has granted medRxiv a license to display the preprint in perpetuity.

It is made available under a CC-BY-ND 4.0 International license .

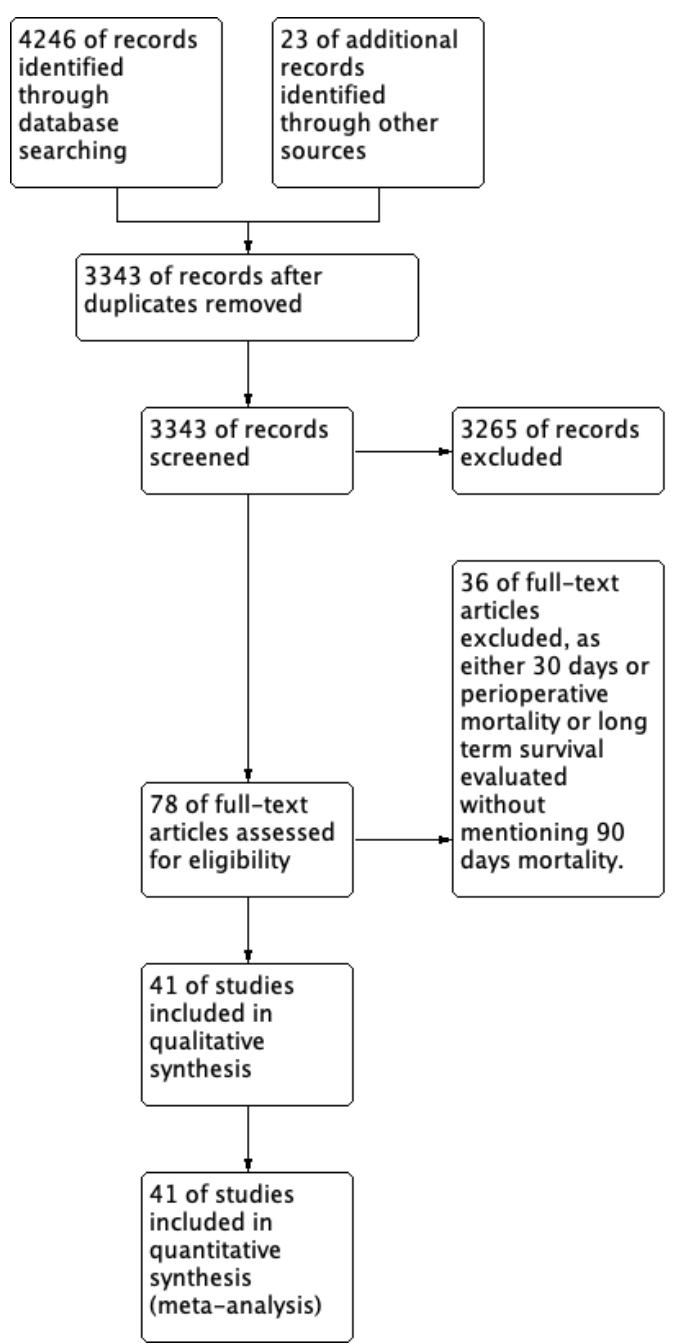

Figure 1 Prisma flow chart. 
medRxiv preprint doi: https://doi.org/10.1101/2021.03.26.21254407; this version posted March 29, 2021. The copyright holder for this preprint (which was not certified by peer review) is the author/funder, who has granted medRxiv a license to display the preprint in perpetuity.

It is made available under a CC-BY-ND 4.0 International license .

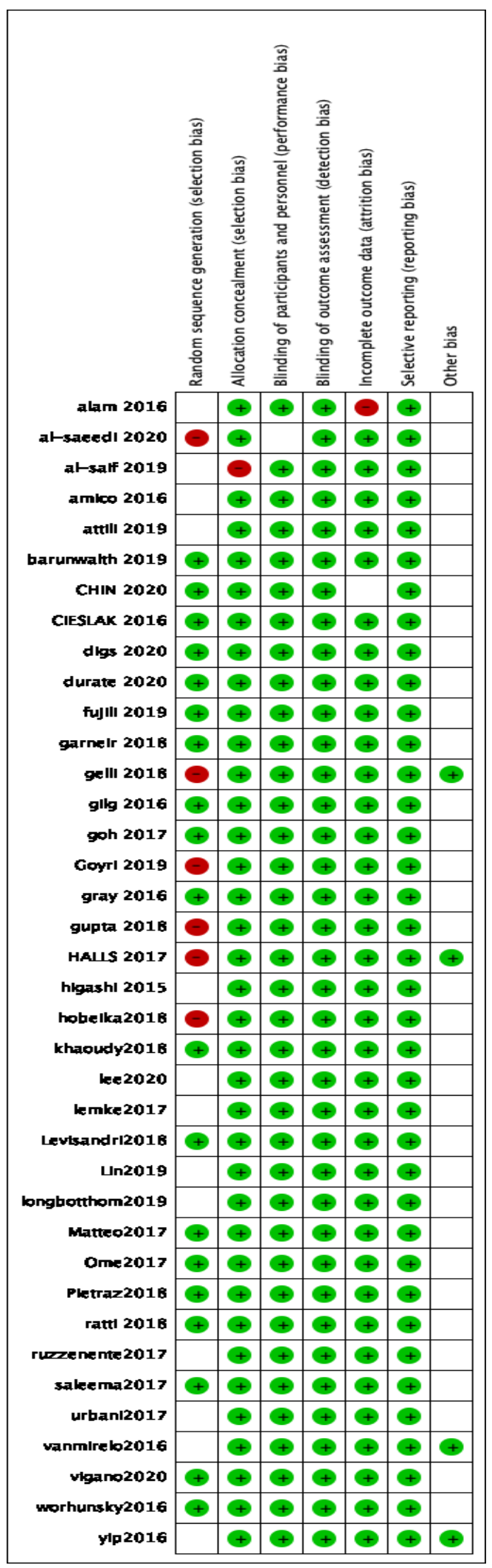


Figure 2. Risk of Bias summary

Table 1: Study Characteristics

\begin{tabular}{|c|c|c|c|c|c|c|c|c|c|c|}
\hline STUDY & $\begin{array}{l}\text { MORTALI } \\
\text { TY }\end{array}$ & total & $\begin{array}{l}90 \text { day } \\
\text { mortali } \\
\text { ty }(\%)\end{array}$ & $\begin{array}{l}\text { Major } \\
\text { HEPATECTO } \\
\text { MY }\end{array}$ & $\begin{array}{l}\text { Open } \\
\text { surge } \\
\text { ry }\end{array}$ & $\begin{array}{l}\text { Cirrho } \\
\text { sis } \\
\text { Present }\end{array}$ & $\begin{array}{l}\text { Age } \\
\text { (media } \\
\text { n) }\end{array}$ & $\begin{array}{l}\text { bloo } \\
\text { d } \\
\text { loss } \\
\text { (ml) }\end{array}$ & $\begin{array}{l}\text { hepatocellu } \\
\text { lar } \\
\text { carcinoma } \\
\text { (n) }\end{array}$ & $\begin{array}{l}\text { Colorec } \\
\text { tal } \\
\text { metasta } \\
\text { sis (n) }\end{array}$ \\
\hline al-saeedi2020 & 21 & 209 & 10 & 209 & 209 & 83 & 60 & $\begin{array}{l}150 \\
0\end{array}$ & 16 & 59 \\
\hline al-saif2019 & 5 & 111 & 4.5 & 48 & 89 & & 52.6 & & 14 & 1 \\
\hline alam2016 & 4 & 77 & 5.2 & 45 & 77 & & 49 & & 11 & 35 \\
\hline amico2016 & 6 & 84 & 7.1 & 38 & 84 & 6 & 54.01 & & 9 & 30 \\
\hline atili2019 & 1 & 10 & 10 & 10 & 8 & 0 & 60.3 & & 3 & 0 \\
\hline $\begin{array}{l}\text { braunwarth20 } \\
19\end{array}$ & 19 & 458 & 4.1 & 242 & 430 & 26 & 61 & 400 & 49 & 149 \\
\hline chin2020 & 24 & 472 & 5.1 & 56 & 472 & 168 & 62 & 682 & 309 & 163 \\
\hline $\begin{array}{l}\text { CHOPINET20 } \\
18\end{array}$ & 7 & 75 & 9.3 & 75 & 75 & 75 & 60 & 209 & 75 & 0 \\
\hline $\begin{array}{l}\text { CIESLAK201 } \\
6\end{array}$ & 12 & 163 & 7.4 & 163 & 163 & 103 & 63 & 211 & 12 & 0 \\
\hline DESARI2018 & 51 & 1269 & 4 & 645 & 1269 & 289 & 65.3 & & & \\
\hline DIGS2020 & 474 & 4263 & 11.1 & 4263 & 4263 & & 60 & & & \\
\hline Durate2020 & 14 & 178 & 7.8 & 178 & 131 & 22 & 58 & 450 & & \\
\hline fujii2019 & 6 & 103 & 5.8 & 103 & 103 & 63 & 67 & $\begin{array}{l}250 \\
0\end{array}$ & & \\
\hline garnier2018 & 5 & 111 & 4.5 & 111 & 111 & 37 & 66 & & 9 & 66 \\
\hline gelli2018 & 117 & 1803 & 6.5 & 619 & 1803 & 226 & 61 & & & \\
\hline gilg2016 & 138 & 4460 & 3.1 & 1615 & & & 64 & & 393 & 2644 \\
\hline Goh2017 & 1 & 195 & 0.5 & 12 & 0 & 50 & 60 & 200 & 102 & 46 \\
\hline Grey2016 & 3 & 66 & 4.5 & 31 & 62 & & 62 & & 18 & 33 \\
\hline gupta2018 & 0 & 26 & 1.9 & 12 & 26 & & 82 & 400 & 4 & 20 \\
\hline Goyri2019 & 17 & 701 & 2.4 & 348 & & & 63 & & 76 & 491 \\
\hline halls2017 & 16 & 2861 & 0.6 & 429 & 222 & 220 & 64 & & 189 & 1630 \\
\hline higashi2015 & 8 & 144 & 5.6 & 138 & 144 & & 65.1 & & 91 & 12 \\
\hline hobeika2018 & 34 & 3150 & 1.1 & 80 & 0 & 774 & 62 & 350 & 1247 & 714 \\
\hline
\end{tabular}


medRxiv preprint doi: https://doi.org/10.1101/2021.03.26.21254407; this version posted March 29, 2021. The copyright holder for this preprint (which was not certified by peer review) is the author/funder, who has granted medRxiv a license to display the preprint in perpetuity.

It is made available under a CC-BY-ND 4.0 International license.

\begin{tabular}{|c|c|c|c|c|c|c|c|c|c|c|}
\hline khaoudy2018 & 90 & 1906 & 4.7 & 1334 & & 686 & 67.6 & & 21 & 24 \\
\hline lee2020 & 0 & 72 & 0.7 & 72 & & & 57 & & 48 & 9 \\
\hline lemke2017 & 39 & 749 & 5.2 & 516 & 681 & 25 & 64 & & 56 & 489 \\
\hline $\begin{array}{l}\text { Levisandri201 } \\
8\end{array}$ & 9 & 225 & 4 & 225 & & & 62.4 & 400 & 77 & 106 \\
\hline Lin2019 & 3 & 281 & 1.1 & & 232 & & 55 & 300 & & \\
\hline $\begin{array}{l}\text { longbotthom } 20 \\
19\end{array}$ & 8 & 283 & 2.8 & 283 & 283 & 124 & 62 & & 36 & 237 \\
\hline $\begin{array}{l}\text { longbotthom1. } \\
2019\end{array}$ & 4 & 49 & 8.2 & 49 & 49 & 20 & 78 & & & \\
\hline Matteo2017 & 2 & 340 & 0.6 & 48 & 340 & & 65 & 300 & 82 & 196 \\
\hline Ome2017 & 1 & 142 & 0.7 & 0 & 79 & 47 & 68 & 600 & & \\
\hline Pietraz2018 & 5 & 195 & 2.6 & 47 & 0 & & 68.2 & & 22 & 130 \\
\hline ratti2018 & 4 & 204 & 2 & 114 & 102 & 8 & 62 & & & \\
\hline ruzzenente 2017 & 11 & 803 & 1.4 & 242 & 803 & 109 & 65.54 & & 176 & 279 \\
\hline saleema2017 & 5 & 75 & 6.7 & 30 & 75 & 30 & 52 & 665 & 37 & 10 \\
\hline urbani2017 & 1 & 60 & 1.7 & 0 & 60 & & 60 & 150 & 7 & 48 \\
\hline vanmirelo2016 & 37 & 956 & 3.9 & 466 & 956 & 320 & 64 & 600 & 61 & 657 \\
\hline vigano2020 & 50 & 2212 & 2.3 & 2212 & 2212 & 0 & 62 & & 414 & \\
\hline $\begin{array}{l}\text { worhunsky201 } \\
6\end{array}$ & 2 & 167 & 1.2 & 30 & 0 & 48 & 58 & 100 & 56 & \\
\hline yip2016 & 3 & 223 & 1.3 & 103 & 200 & & 67 & & 25 & \\
\hline zarour2019 & 1 & 45 & 2.2 & 23 & 45 & 8 & 75 & & 45 & \\
\hline
\end{tabular}


medRxiv preprint doi: https://doi.org/10.1101/2021.03.26.21254407; this version posted March 29, 2021. The copyright holder for this preprint (which was not certified by peer review) is the author/funder, who has granted medRxiv a license to display the preprint in perpetuity.

It is made available under a CC-BY-ND 4.0 International license.

Studies

al-saeedi 2020

al-saif 2019

alam 2016

amico 2016

atili 2019

braunwarth 2019

chin 2020

CHOPINET 2018

CIESLAK 2016

DESARI 2018

DIGS 2020

Durate 2020

fujii 2019

garnier 2018

gelli 2018

gilg 2016

Goh 2017

Grey 2016

gupta 2018

Goyri 2019

halls 2017

higashi 2015

hobeika 2018

khaoudy 2018

lee 2020

lemke 2017

livesandri 2016

lin 2019

longbotthom 2019

longbotthom 12019

Matteo 2017

Ome 2017

Pietraz 2018

ratti 2018

ruzzenente 2017

saleema 2017

urbani 2017

vanmirelo 2016

vigano 2020

worhunsky 2016

yip 2016
Estimate (958 C.I.)

$0.100(0.060,0.141)$

$0.045(0.006,0.084)$

$0.052(0.002,0.102)$

$0.071(0.016,0.127)$

$0.100(0.000,0.286)$

$0.041(0.023,0.060)$

$0.051(0.031,0.071)$

$0.093(0.027,0.159)$

$0.074(0.034,0.114)$

$0.040(0.029,0.051)$

$0.111(0.102,0.121)$

$0.079(0.039,0.118)$

$0.058(0.013,0.103)$

$0.045(0.006,0.084)$

$0.065(0.054,0.076)$

$0.031(0.026,0.036)$

$0.005(0.000,0.015)$

$0.045(0.000,0.096)$

$0.019(0.000,0.069)$

$0.024(0.013,0.036)$

$0.006(0.003,0.008)$

$0.056(0.018,0.093)$

$0.011(0.007,0.014)$

$0.047(0.038,0.057)$

$0.007(0.000,0.026)$

$0.052(0.036,0.068)$

$0.040(0.014,0.066)$

$0.011(0.000,0.023)$

$0.028(0.009,0.048)$

$0.082(0.005,0.158)$

$0.006(0.000,0.014)$

$0.007(0.000,0.021)$

$0.026(0.003,0.048)$

$0.020(0.001,0.039)$

$0.014(0.006,0.022)$

$0.067(0.010,0.123)$

$0.017(0.000,0.049)$

$0.039(0.026,0.051)$

$0.023(0.016,0.029)$

$0.012(0.000,0.028)$

$0.013(0.000,0.029)$

\section{Ev/Trt}

$21 / 209$

$5 / 111$

$4 / 77$

$6 / 84$

$1 / 10$
$19 / 458$

$24 / 472$

$7 / 75$

$12 / 163$

$51 / 1269$

$474 / 4263$

$14 / 178$

$6 / 103$

$5 / 111$

$117 / 1803$

$138 / 4460$

$1 / 195$

$3 / 66$

$0 / 26$

$17 / 701$

$16 / 2861$

$8 / 144$

$34 / 3150$

$90 / 1906$

$0 / 72$

$39 / 749$

$9 / 225$

$3 / 281$

$8 / 283$

$4 / 49$

$2 / 340$

$1 / 142$

$5 / 195$

4/204

$11 / 803$

$5 / 75$

$1 / 60$

$37 / 956$

$50 / 2212$

$2 / 167$

$3 / 223$

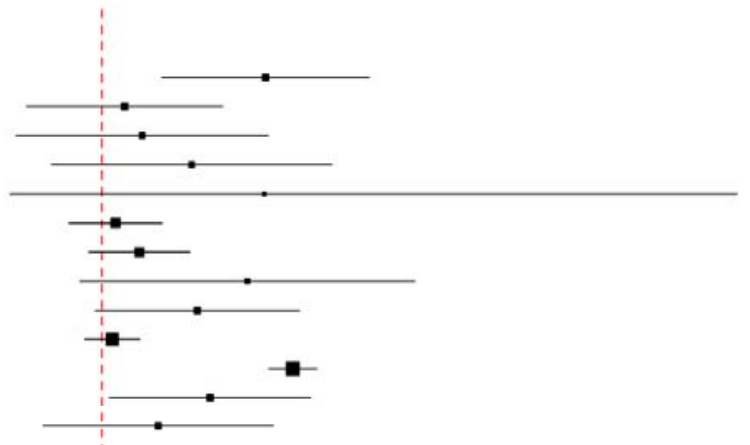

Overall $\left(\left.\right|^{\wedge} 2=9463 \%, P<0.001\right) \quad 0.036(0.028,0.044) \quad 1257 / 29931$

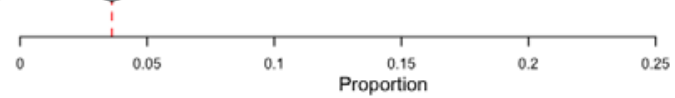




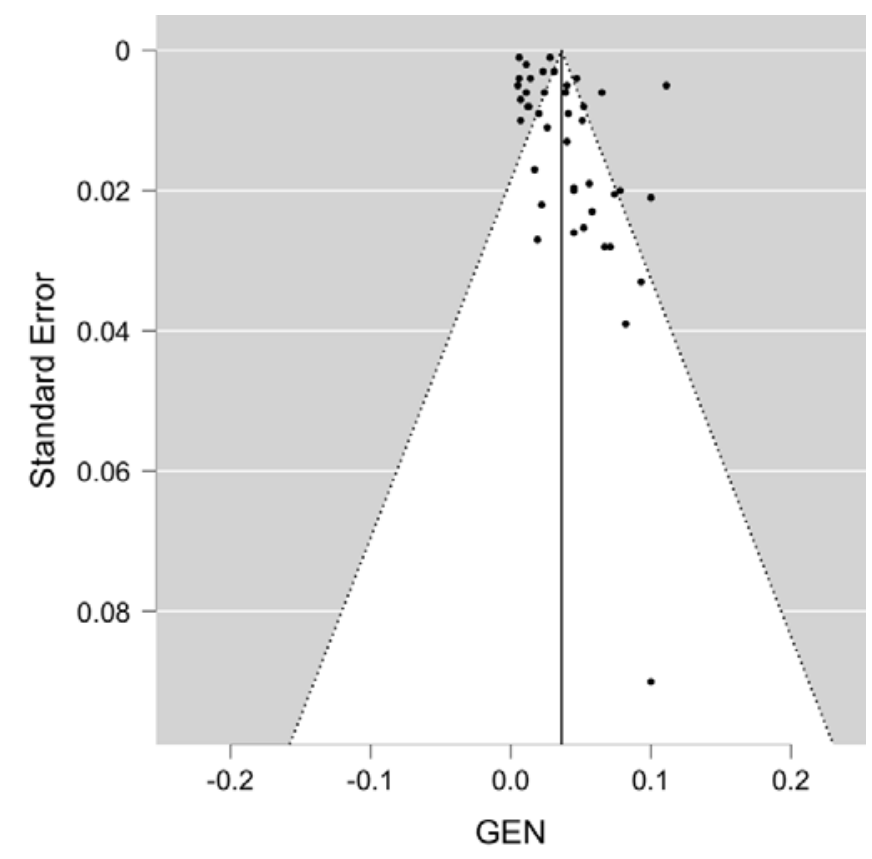

Figure 4. Funnel Plot for publication bias. (Egger's test showed significant publication bias, p $<0.001)$.

Table 2: Univariate and Multivariate meta regression analysis.

\begin{tabular}{|c|c|c|c|c|}
\hline Factors & $\begin{array}{l}\mathrm{Z} \text { value in } \\
\text { univariate } \\
\text { metaregression }\end{array}$ & $\begin{array}{l}\mathrm{P} \text { value in } \\
\text { univariate } \\
\text { metaregression }\end{array}$ & $\begin{array}{l}\mathrm{Z} \text { value in } \\
\text { multivariate } \\
\text { metaregression } \\
\text { (ALL } \\
\text { FACTORS) }\end{array}$ & $\begin{array}{l}\mathrm{P} \text { value in } \\
\text { multivariate } \\
\text { metaregression } \\
\text { (ALL } \\
\text { FACTORS) }\end{array}$ \\
\hline $\begin{array}{l}\text { Major } \\
\text { Hepatectomy }\end{array}$ & 3.995 & $<0.001$ & 2.945 & 0.003 \\
\hline Open Surgery & 4.762 & $<0.001$ & 2.504 & 0.012 \\
\hline Blood loss & 3.073 & 0.002 & 0.762 & 0.446 \\
\hline Age & -1.046 & 0.296 & -1.79 & 0.73 \\
\hline Cirrhosis & -0.579 & 0.562 & 3.004 & 0.003 \\
\hline
\end{tabular}




\begin{tabular}{|l|l|l|l|l|}
\hline Hepatocellular & -1.633 & 0.103 & -0.608 & 0.543 \\
Carcinoma & & & & \\
\hline Colorectal Liver & -1.210 & 0.226 & $\mathbf{- 4 . 1 1 6}$ & $<\mathbf{0 . 0 0 1}$ \\
\hline
\end{tabular}

al-saeedi2020

braunwarth2019

chin2020

CHOPINET2018

CIESLAK2016

Goh2017

hobeika2018

saleema2017

vanmirelo2016

worhunsky2016
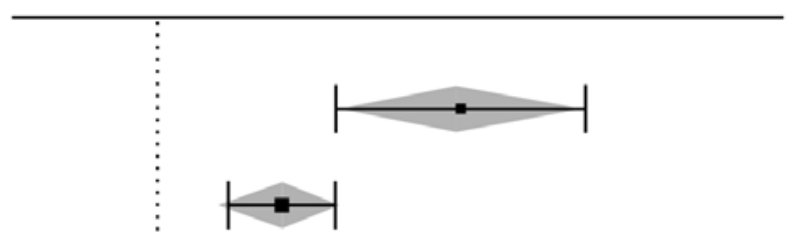

$0.10[0.06,0.14]$

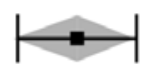

$0.04[0.02,0.06]$

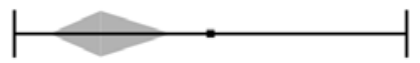

$0.05[0.03,0.07]$

$0.09[0.03,0.16]$

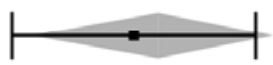

$0.07[0.03,0.11]$

$0.01[-0.00,0.01]$

$0.01[0.01,0.01]$

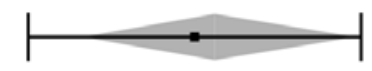

$0.07[0.01,0.12]$

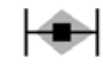

$0.04[0.03,0.05]$

$0.01[-0.00,0.03]$

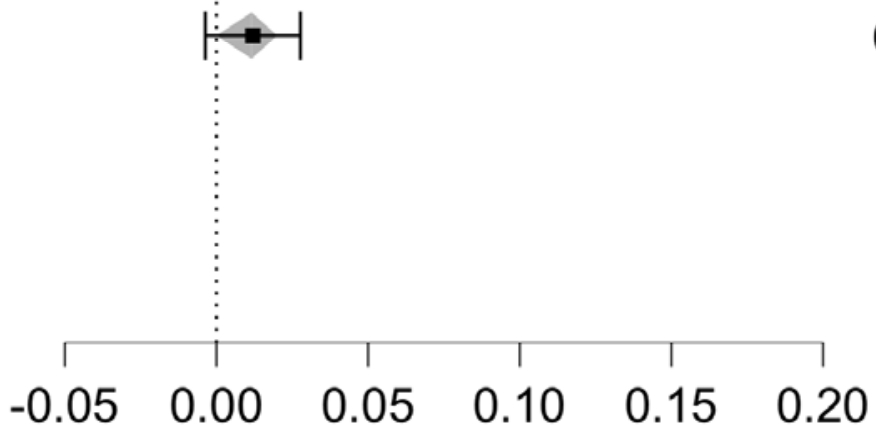

Observed Outcome

Figure 5: Forest plot multivariate metaregression. (grey squares is expected effect size with regard to covariate) 
medRxiv preprint doi: https://doi.org/10.1101/2021.03.26.21254407; this version posted March 29, 2021. The copyright holder for this preprint (which was not certified by peer review) is the author/funder, who has granted medRxiv a license to display the preprint in perpetuity.

It is made available under a CC-BY-ND 4.0 International license .

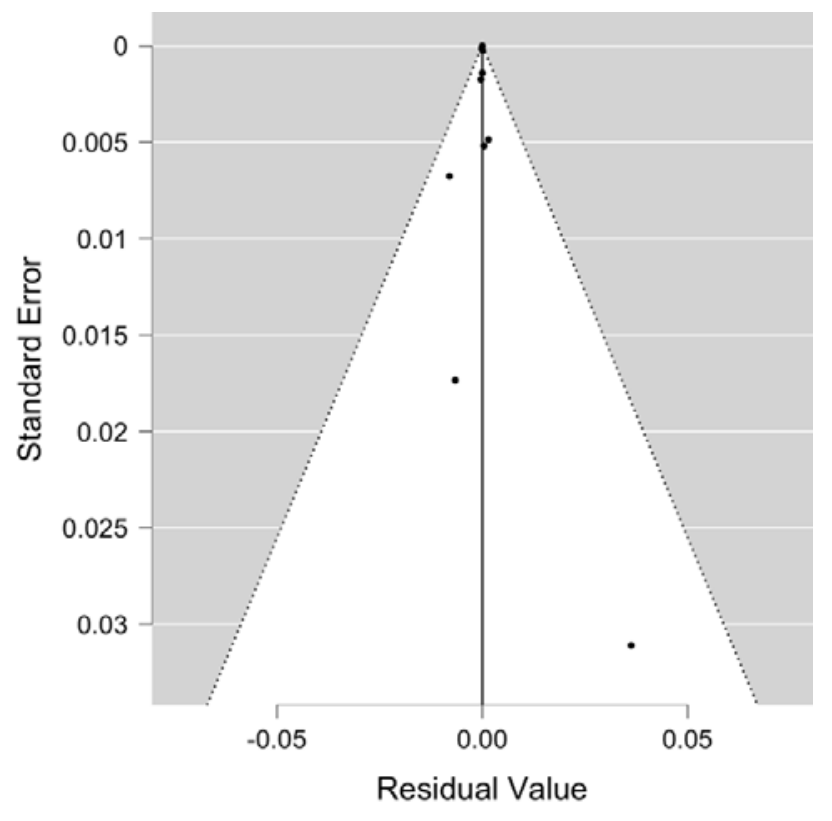

Figure 6. Funnel plot of publication bias for studies containing all the covariate in metaregression. $(\mathrm{p}=0.285$ by egger's test) 


\section{Normal Q-Q Plot}

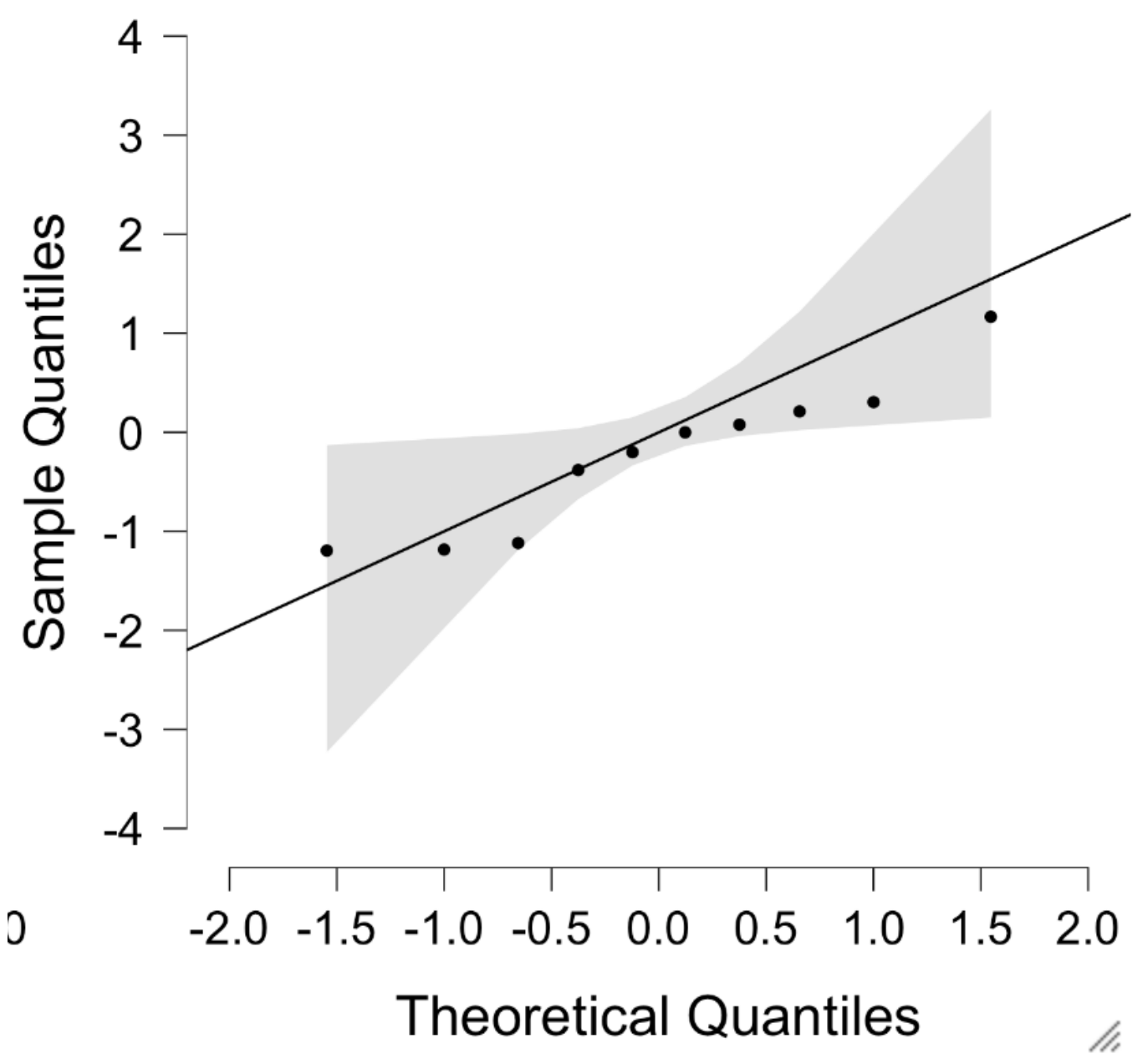

Figure 7 Normal Q-Q plot. 